\title{
グレリンの基礎と臨床応用
}

\section{寒川 賢治}

国立循環器病研究センター

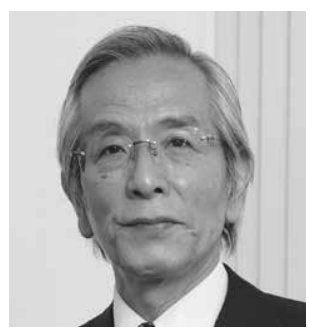

我々のグループでは、生体内の複雑な情報伝達機序を解明するためのアプローチの一つとして、新し い生理活性ペプチド（ペプチドホルモン）の探索・発見とその機能の解明を目指している。未知のペプ チドの探索は容易ではないが、その発見は大きな breakthrough に繋がる。

我々はこれまでに、ナトリウム利尿ペプチド・ファミリー（ANP：1984 年、BNP：1988 年、CNP： 1990 年）やアドレノメデュリン（1993 年）などの多くの新規ペプチドの発見に成功し、新たな循環調 節系の存在とその生理的意義を明らかにしてきた。ANP と BNPについては 1990 年代半ばより、心不 全の診断薬・治療薬として臨床応用されている。

一方、ポストゲノム研究として、1990 年代後半から製薬企業を含めた世界中の多くのグループにより、 オーファン GPCR をターゲットにしたリガンド探索が進められていた。我々のグループでもオーファ ン受容体 GHS-R の内因性リガンドの探索を進めた結果、強力な成長ホルモン (GH) 分泌促進作用を 有する新規ペプチド“グレリン (Ghrelin) ”の発見に成功した（1999年）。グレリンは 28 残基のアミ ノ酸からなり、脂肪酸（オクタン酸）でアシル化修飾されたこれまでにないユニークな構造のペプチド であり、この脂肪酸修飾は活性発現に必須である。

グレリンは GH 分泌促進とともに摂食促進作用を有する。グレリンの主要な産生部位は胃の内分泌細 胞であり、血中に分泌されたグレリンは迷走神経求心路を介して、視床下部に摂食や GH 分泌のシグナ ルを伝達する。また、脳内の視床下部にも存在し、中枢性の GH 分泌調節や摂食調節に関わる。このよ うに、グレリンは Brain-Gut ホルモンであり、末梢投与によっても GH 分泌や食欲を促進する。また肥 満や拒食症などの病態やエネルギー代謝調節にも密接に関与し、消化管に於いては胃酸分泌や消化管運 動を促進する。さらに、血管拡張や心血管系の保護作用などの循環器系における機能や作用機序も明ら かになりつつある。これらの作用の多くは自律神経系を介したものであり、グレリンによる交感神経抑 制、副交感神経立進の自律神経系の調節が生体のホメオスタシ維持に非常に重要であると考えられてい る。

本講演では、グレリンを中心に生体内の新規生理ペプチドの探索・発見、および生理機能解析や治療 応用の可能性について紹介したい。 